\title{
AKTIVITAS ANTIFUNGI EKSTRAK DAUN PICUNG TERHADAP CENDAWAN Botryodiplodia theobromae PENYEBAB MATI PUCUK BIBIT JABON MERAH
}

\author{
Antifungal Activity of Picung Leaf Extracts Against Botryodiplodia theobromae A Dieback \\ Fungus of Jabon Merah Seedling
}

\author{
L.M. Alfin Agushara Bena', Achmad ${ }^{2}$, dan Syamsul Falah ${ }^{3}$ \\ ${ }^{1)}$ Mahasiswa pascasarjana Program Studi Silvikutur Tropika, Fakultas Kehutanan IPB, \\ ${ }^{2)}$ Staf Pengajar pada Departemen Silvikultur, Fakultas Kehutanan IPB, \\ ${ }^{3)}$ Staf Pengajar pada Departemen Biokimia, Fakultas Matematika dan Ilmu Pengetahuan Alam IPB, Kampus \\ Dramaga, Bogor-16680.
}

\begin{abstract}
Invasion of Botryodiplodia theobromae as a dieback fungus on jabon merah (Anthocephalus macrophyllus) seedlings is a crucial issues. This pathogenic fungus needs to be controlled precisely. Phytochemical compounds of plant material is one alternative fungicides. Crude extracts of picung (Pangium edule) leaf in water and methanol solvent known to have antifungal potential. However, its activity against B. theobromae need to be revealed. In vitro assay aimed to measuring antifungal activity of water and methanol extracts of picung leaf on controlling growth of $\mathrm{B}$. theobromae pathogenic fungus. Hot water extraction and maceration in methanol was conducted to obtain crude extract materials. In-vitro antifungal assay of water and methanol extracts of picung leaf was conducted by food poisoning method on Potato Dextrose Agar media. The results showed that water and methanol extracts of pangi leaf be able to suppress the growth of B. theobromae on the first day of observation, with the highest antifungal index reached $100 \%$ at concentration of $25 \mathrm{mg} / \mathrm{mL}$ and $50 \mathrm{mg} / \mathrm{mL}$, respectively. This indicates that water and methanol extracts of picung leaf have antifungal activity. Generally, there was a trend of decrease in antifungal index over time.
\end{abstract}

Key words: antifungal activity, Botryodiplodia theobromae, jabon merah, picung

\section{PENDAHULUAN}

Serangan cendawan patogen penyakit mati pucuk (dieback) pada bibit tanaman jabon merah (Anthocephalus macropyllus) menjadi masalah krusial yang perlu dikendalikan. Kondisi bibit yang masih sukulen rentan terhadap gangguan penyakit sehingga berpotensi menjadi inang bagi patogen (Aisah et al. 2015). Cendawan patogen penyebab mati pucuk pada bibit Jabon merah adalah Botryodiplodia theobromae. Yanti et al. (2015) melaporkan kejadian penyakit mati pucuk pada bibit jabon merah yang terinfeksi $B$. theobromae mencapai $100 \%$ dengan tingkat keparahan $38 \%$.

B. theobromae (sinonim: Lasiodiplodia theobromae) merupakan anamorf dari Botryosphaeria rhodina, konidia berbentuk elipsoidal bersel dua (Watanabe 2002). Cendawan ini diketahui sebagai patogen tanaman berkayu khususnya di daerah tropis (Ellis et al. 2007). $B$. theobromae menyebabkan busuk jaringan pada yam putih (Dioscorea rotundata) di Nigeria (Markson et al. 2012), patogen intercrops di Ghana menyebabkan busuk jaringan pada buah coklat, mangga, pisang dan yam (Twumasi et al. 2014), patogen mati pucuk pada Pouteria sapota di Meksiko (Pedraza et al. (2013), dan merupakan patogen primer penyakit mati pucuk pada bibit jabon putih (A. cadamba) dengan tingkat patogenisitas yang tinggi hingga menimbulkan kematian bibit (Aisah 2014).

Salah satu cara pengendalian $B$. theobromae yang potensial untuk dikembangkan adalah pemanfaatan biopestisida yang berasal dari ekstrak tumbuhan, cara pengendalian tersebut lebih ramah lingkungan. Menurut Chye dan Sim (2009) metabolit sekunder tumbuhan merupakan sumber terbaik senyawa fitokimia sebagai antimikroba. Eksplorasi dan studi efektifitasnya terus dilakukan saat ini untuk memberikan informasi alternatif bahan aktif pestisida. Picung (Pangium edule) adalah salah satu spesies tumbuhan yang telah dilaporkan memiliki potensi antimikroba.

Picung merupakan anggota famili Silacaceae (sebelumnya ditempatkan pada Flacourtiaceae) yang dikenal dengan nama lokal kluwak, pucung, pucong, pakem (Jawa), kepayang, kapenceung, kapecong, kepayang, simuang, kayu tuba buwah (Sumatera), picung, pucung, pacung (Sunda) (Lim 2013). Daun picung dimanfaatkan sebagai obat anti-jamur pada kulit manusia atau sebagai pembunuh kuman (Partomihardjo dan Rugayah 1989). Ekstrak air daun atau buah segar picung digunakan sebagai obat luar untuk meredakan proses pembusukan jaringan (putrefaksi) dan mengeliminasi parasit pada manusia (Wiart 2006). Ekstrak kasar metanol daun picung bersifat antibakteri Bacillus cereus, Escherichia coli, Staphylococcus aureus, Salmonella typhimurium dan Pseudomonas 
aeruginosa (Suhardi 2009) serta menunjukkan aktivitas antifungi terhadap cendawan patogen antraknosa Colletotrichum gloeosporioides pada mangga (Mangifera indica) dan C. capsici pada cabai (Capsicum annuum) (Johnny et al. 2010; 2011).

Potensi antimikroba khususnya antifungi dari ekstrak air dan metanol daun picung dalam mengendalikan cendawan $B$. theobromae, patogen mati pucuk bibit jabon merah belum pernah dilaporkan. Oleh sebab itu, studi aktivitas antifungi dari ekstrak air dan metanol daun picung perlu dilakukan.

\section{TUJUAN PENELITIAN}

Penelitian ini bertujuan untuk mengungkap aktivitas antifungi dari ekstrak air dan ekstrak metanol daun picung dalam mengendalikan pertumbuhan cendawan $B$. theobromae penyebab mati pucuk bibit jabon merah secara in vitro.

\section{BAHAN DAN METODE}

\section{Tempat dan Waktu Penelitian}

Penyiapan isolat cendawan patogen B. theobromae serta uji aktivitas antifungi dari ekstrak air dan ekstrak metanol daun picung dilakukan di Laboratorium Penyakit Hutan Institut Pertanian Bogor (IPB). Ekstraksi daun picung dilakukan di Laboratorium Kimia Kayu IPB. Penelitian ini dilaksanakan pada bulan Maret sampai Juli 2016.

\section{Alat dan Bahan Penelitian}

Peralatan yang digunakan adalah cawan petri kaca diameter $9 \mathrm{~cm}$, cork borer diameter 6mm, mikropipet, inkubator, mikroskop cahaya, laminar air flow, autoclave, water bath, rotary vacuum evaporator, beaker glass, toples kaca, erlenmeyer, tabung reaksi, dan kamera digital.

Bahan yang digunakan adalah daun picung yang diperoleh dari pohon yang tumbuh di hutan kampus IPB Darmaga, isolat B. theobromae koleksi Laboratorium Penyakit Hutan IPB, media biakan Potato Dextrose Agar (PDA), chloramphenicol, alkohol 70\%, aquades steril, metanol $98 \%$, dan kertas saring Whatman no.1 (diameter $150 \mathrm{~mm}$ ).

\section{Studi pendahuluan}

Isolat cendawan patogen $B$. theobromae diperoleh dari koleksi Laboratorium Penyakit Hutan IPB. Isolat kemudian diremajakan dan dipelihara pada media kultur PDA selektif dengan tambahan antibiotik chloramphenicol $50 \quad \mathrm{mg} / \mathrm{L}$. Penambahan chloramphenicol pada media PDA merujuk pada Twumasi et al. (2014) untuk menghindari kontaminasi bakteri.

Bahan ekstraksi daun picung berupa simplisia kering dari daun picung tua. Daun tua yang dipilih memiliki ciri helaian daun berbentuk jantung melebar di pangkal dan ujung daun meruncing, permukaan atas daun berwarna hijau mengkilap, permukaan bawahnya berbulu rapat warna coklat (Sari dan Suhartati 2015). Daun dikering-anginkan selama sepuluh hari kemudian digiling hingga halus (Johnny et al. 2011; Mora et al. 2014). Simplisia kering kemudian ditetapkan kadar air yang mengacu pada Suhardi (2009), sehingga diperoleh kadar air simplisia kering $8.16 \%$.

Ekstraksi dilakukan menggunakan dua jenis pelarut polar, yaitu air (aquades) dan metanol teknis 98\%. Kedua pelarut dipilih berdasarkan pertimbangan ekonomis dan kemudahan aplikasi. Metode ekstraksi air panas dan metanol merujuk pada Falah et al. (2010) dan Suhardi (2009) dengan modifikasi. Perbandingan bobot simplisia dengan volume pelarut untuk ekstraksi air panas dan maserasi, masing-masing 1:4 dan 1:3. Ekstraksi dengan air panas dilakukan pada waterbath suhu $100^{\circ} \mathrm{C}$ selama 4 jam, sedangkan ekstraksi dengan pelarut metanol dilakukan pada suhu ruangan selama 3 hari dan dimaserasi kembali sebanyak 3 kali. Ekstrak disaring menggunakan kertas saring Whatman no.1 dan dikeringkan menggunakan rotary vacuum evaporator pada suhu $60^{\circ} \mathrm{C}$. Rendemen ekstrak air dan metanol yang diperoleh masing-masing sebesar $14.91 \%$ dan $16.01 \%$.

Ekstrak kering berupa padatan digunakan untuk membuat larutan perlakuan. Ekstrak kering dilarutkan dalam aquades steril dengan konsentrasi sesuai perlakuan. Khusus untuk ekstrak metanol, sebelum dilarutkan ke dalam aquades didahului pemberian dua tetes $( \pm 0.1 \mathrm{~mL})$ pelarut untuk melarutkan ekstrak, hal yang sama juga dilakukan pada larutan perlakuan kontrol.

Konsentrasi ekstrak perlakuan yang diujikan adalah: (A) kontrol, aquades tanpa ekstrak; (B) ekstrak 25 $\mathrm{mg} / \mathrm{mL}$; (C) ekstrak $50 \mathrm{mg} / \mathrm{mL}$; (D) ekstrak $75 \mathrm{mg} / \mathrm{mL}$; (E) ekstrak $100 \mathrm{mg} / \mathrm{mL}$. Larutan perlakuan disterilisasi menggunakan autoclave pada suhu $121^{\circ} \mathrm{C}$ selama 15 menit, merujuk pada Achmad et al. (2012) dan Winara (2014).

\section{Uji Aktivitas Antifungi Ekstrak Daun Picung secara In Vitro}

Pengujian aktivitas antifungi ekstrak daun picung terhadap $B$. theobromae pada media padat dilakukan berdasarkan metode peracunan makanan (poisoned food technique) (Vyas 1984). Perlakuan ekstrak air dan ekstrak metanol diuji terpisah, masing-masing ekstrak terdiri atas 5 perlakuan. Sebanyak $2 \mathrm{~mL}$ dari masingmasing larutan perlakuan dimasukkan ke dalam cawan pertri steril diameter $9 \mathrm{~cm}$, kemudian ke dalam cawan yang sama dicampurkan $10 \mathrm{~mL}$ media PDA, digoyang hingga homogen. Untuk perlakuan kontrol, ditambahkan $2 \mathrm{~mL}$ aquades tanpa ekstrak dan $10 \mathrm{~mL}$ media PDA. Proporsi larutan ekstrak di dalam PDA merujuk pada Abdel-Monaim et al. (2011). Cawan berisi media uji selanjutnya diinokulasi $B$. theobromae dengan cara meletakkan inokulum diameter $6 \mathrm{~mm}$ pada bagian tengah cawan, kemudian diinkubasi selama tiga hari. Pengamatan dilaksanakan setiap hari selama tiga hari. Data yang dikumpulkan adalah rerata pertambahan diameter radial koloni miselia. 
Rancangan percobaan yang digunakan adalah Rancangan Acak Lengkap (RAL) in time (Mattjik dan Sumertajaya 2013) dengan tiga ulangan. Variabel yang dianalisis adalah indeks antifungi ekstrak (IA) menggunakan formula Yang dan Zhang (2012):

$$
\mathrm{IA}(\%)=\left[1-\frac{D \mathrm{a}}{D \mathrm{~b}}\right] \times 100,
$$

$D$ a adalah rerata pertambahan diameter radial koloni miselia pada cawan perlakuan ekstrak (cm), dan $D$ b adalah rerata pertambahan diameter radial koloni miselia pada cawan kontrol $(\mathrm{cm})$.

\section{Analisis Data}

Analisis yang digunakan untuk menguji pengaruh perlakuan terhadap variabel pengamatan adalah analisis ragam. Apabila perlakuan menunjukkan pengaruh nyata terhadap variabel yang diamati maka dilanjutkan uji jarak berganda Duncan (Mattjik dan Sumertajaya 2013). Analisis dilakukan dengan bantuan software SPSS versi 17.

\section{HASIL DAN PEMBAHASAN}

\section{Aktivitas Antifungi Ekstrak Daun Picung secara In Vitro}

Ekstrak air dan metanol daun picung secara umum menunjukkan aktivitas antifungi terhadap cendawan $B$. theobromae. Hal ini terlihat pada kurva respon pertumbuhan koloni terhadap pemberian ekstrak air dan metanol, masing-masing disajikan pada Gambar 1 dan 2. Penambahan ekstrak air dan metanol berbagai konsentrasi, nyata menekan pertumbuhan $B$. theobromae.

Penambahan ekstrak air daun picung pada media tumbuh PDA mampu menekan pertumbuhan koloni $B$. theobromae secara nyata dibanding kontrol (Gambar 1). Konsentrasi ekstrak air daun picung 50 dan $75 \mathrm{mg} / \mathrm{mL}$ merupakan konsentrasi yang paling efektif menekan pertumbuhan koloni $B$. theobromae dibanding terhadap kontrol dan perlakuan ekstrak daun picung pada konsentrasi lain.

Seperti halnya aplikasi ekstrak air daun picung, penambahan ekstrak metanol daun picung pada media tumbuh PDA mampu menekan pertumbuhan koloni $B$. theobromae dibandingkan terhadap kontrol. Ekstrak metanol daun picung $100 \mathrm{mg} / \mathrm{mL}$ merupakan konsentrasi yang mampu menekan paling efektif terhadap pertumbuhan koloni B. Theobromae (Gambar 2).

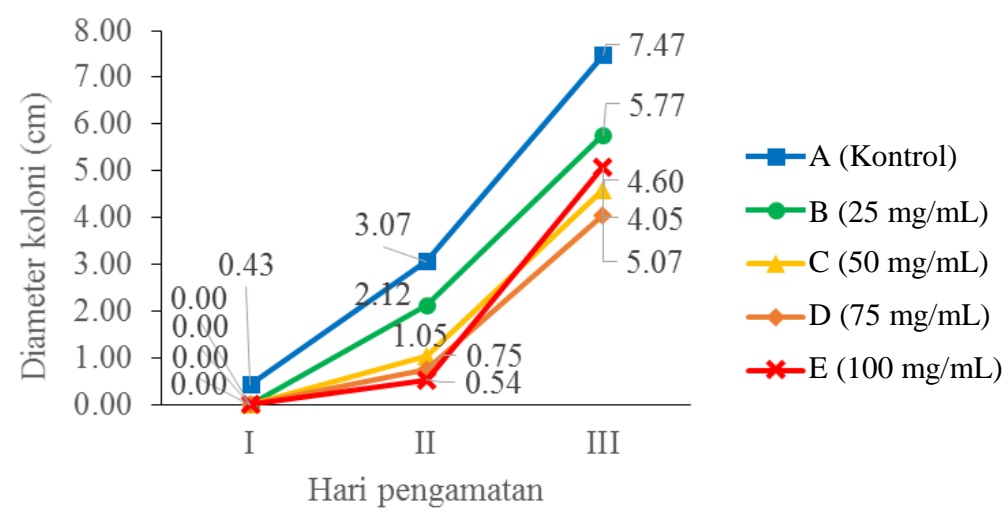

Gambar 1 Respon pertumbuhan koloni B. theobromae terhadap pemberian ekstrak air daun picung selama tiga hari pengamatan

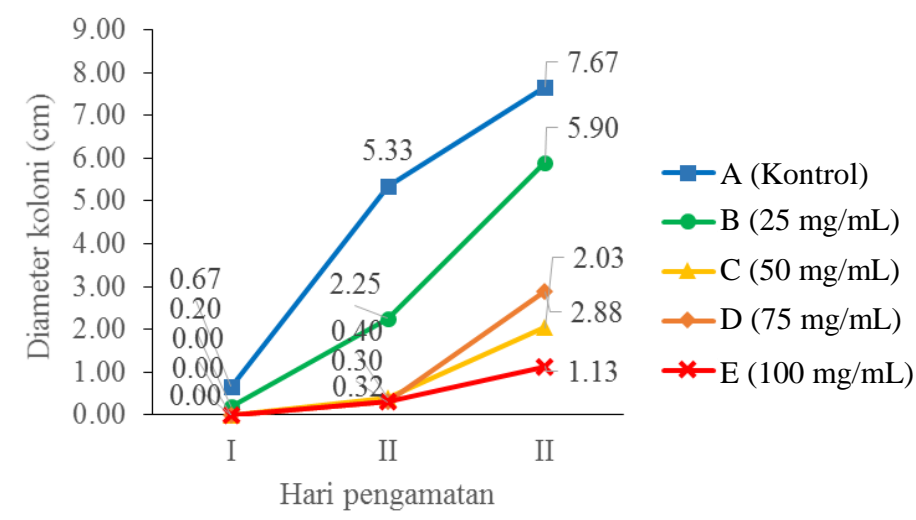

Gambar 2 Respon pertumbuhan koloni B. theobromae terhadap pemberian ekstrak metanol daun picung selama tiga hari pengamatan 


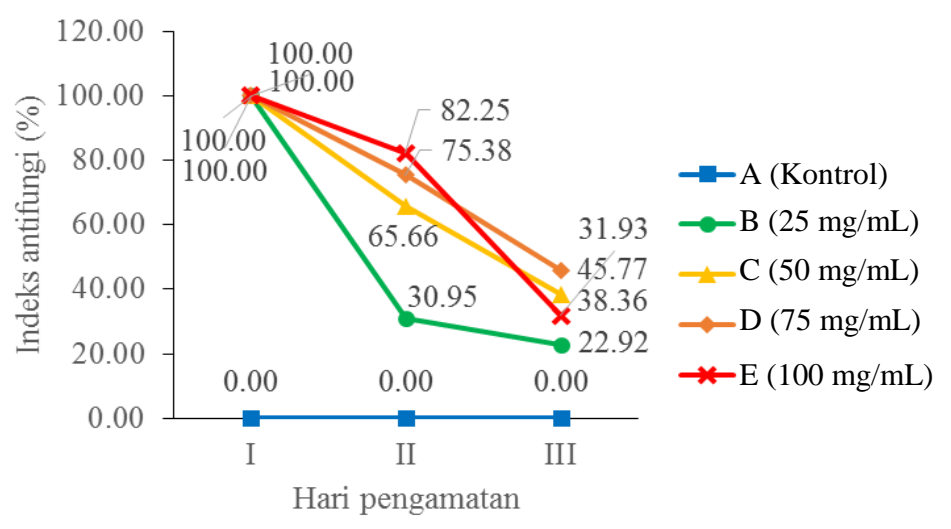

Gambar 3 Indeks antifungi ekstrak air daun picung terhadap B. theobromae

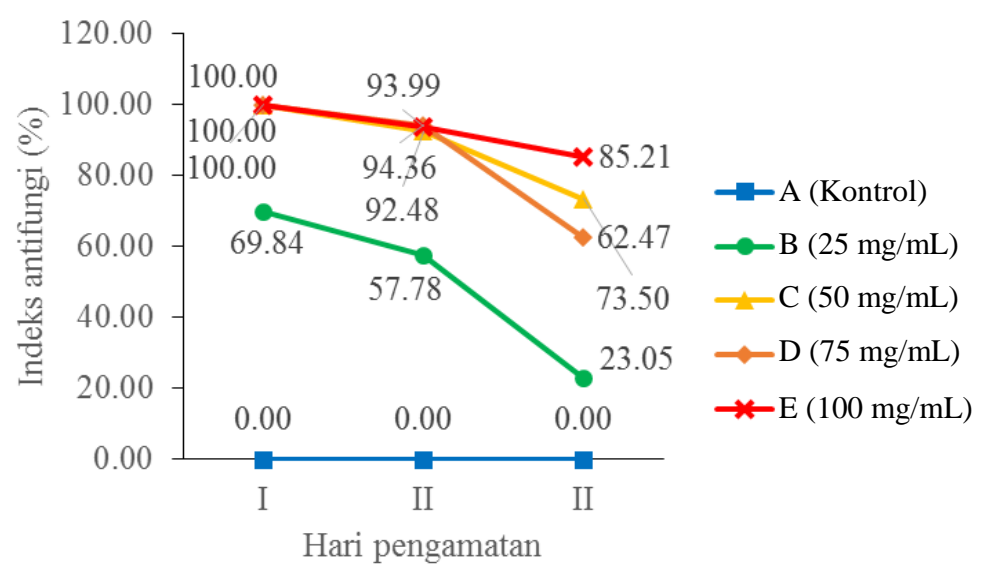

Gambar 4 Indeks antifungi ekstrak metanol daun picung terhadap B. theobromae

Berdasarkan indeks antifungi, ekstrak air dan metanol daun picung mampu menghambat pertumbuhan koloni B. theobromae secara nyata (Gambar 3 dan 4). Semakin tinggi konsentrasi ekstrak daun picung pada media tumbuh PDA, menunjukkan semakin tinggi indeks antifungi dan semakin tinggi daya hambat terhadap pertumbuhan koloni $B$. theobromae. Aplikasi semua perlakuan konsentrasi baik ekstrak air maupun ekstrak metanol daun picung, indeks antifungi menurun pada hari pertama hingga pengamatan hari ketiga.

Indeks antifungi menunjukkan bahwa ekstrak air maupun metanol daun picung mengandung senyawa yang bersifat antifungi dan mampu menekan pertumbuhan koloni $B$. theobromae. Johnny et al. (2010; 2011) menjelaskan aplikasi ekstrak kasar metanol daun picung pada konsentrasi $1 \mu \mathrm{g} / \mathrm{mL}$ dan $0.01 \mu \mathrm{g} / \mathrm{mL}$ masing-masing mampu menekan pertumbuhan Colletotrichum capsici dan $C$. gloeosporioides. Hasil penelitian Syahbirin et al. (2005) menunjukan senyawa fitokimia yang terkandung dalam ekstrak daun picung berupa sianida, alkaloid, flavonoid, tanin, triterpenoid, saponin dan steroidal.
Menurut Sortino et al. (2012) senyawa alkaloid, flavonoid, tanin, terpenoid, saponin dan steroidal merupakan senyawa antifungi. Selain itu, sianida merupakan senyawa toksik terhadap respirasi seluler (Scott 2008). Mekanisme aktivitas antifungi senyawa fitokimia dijelaskan Sortino et al. (2012) sebagai berikut: (1) penghambatan sintesis dinding sel, (2) distrupsi membran sel, dan (3) gangguan metabolisme sel.

Perubahan morfologi hifa $B$. theobromae akibat pemberian ekstrak daun picung yaitu penyimpangan bentuk hifa berupa benjolan (bulging), diameter yang lebih kecil dari ukuran normal dengan cabang yang banyak (Gambar 5). Menurut Aderiye dan Oluwole (2015) aktivitas antifungi mengakibatkan penggelembungan sel hingga terbentuk benjolan pada hifa bahkan pecahnya sel, pertumbuhan hifa menjadi kerdil, pendek, dan memiliki percabangan yang banyak. Diduga bahwa senyawa fitokimia ekstrak daun picung berperan sinergis dalam mempengaruhi metabolisme sel B. theobromae secara luas. 


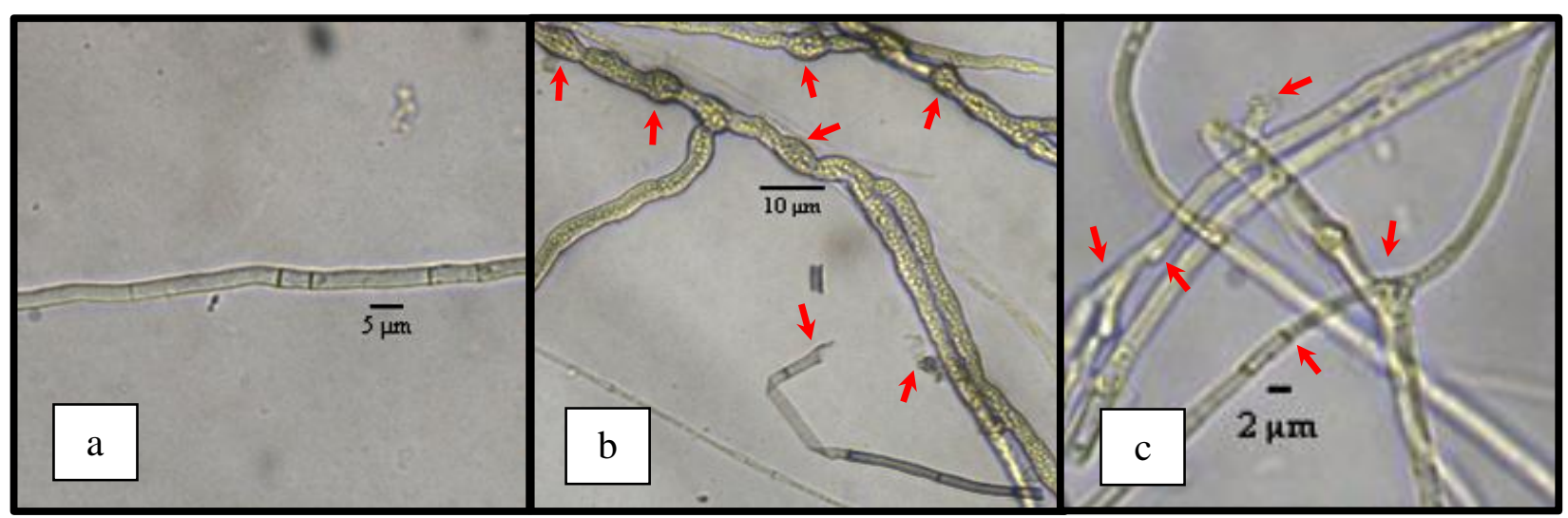

Gambar 5 Morfologi hifa B. theobromae, (a) normal, (b) terbentuk benjolan, (c) ukuran diameter lebih kecil dan bercabang banyak

Pada percobaan yang telah dilakukan, aktivitas antifungi dari ekstrak air maupun metanol daun picung terhadap pertumbuhan $B$. theobromae menurun dari pengamatan pertama sampai pengamatan ketiga. Hal ini disebabkan senyawa fitokimia dari bahan tanaman mudah terdegradasi secara alami sehingga keefektifan segera menurun. Selain itu, diduga cendawan patogen mempunyai resistensi terhadap senyawa fitokimia. Henry dan Nyns (1975) dalam Salisbury dan Ross (1995) menjelaskan beberapa spesies cendawan resisten terhadap sianida yang merupakan senyawa fitokimia.

\section{KESIMPULAN}

Ekstrak air dan ekstrak metanol daun picung memiliki aktivitas antifungi terhadap pertumbuhan $B$. theobromae secara in vitro pada media tumbuh PDA. Aplikasi ekstrak air dan metanol pada konsentrasi 25 $\mathrm{mg} / \mathrm{mL}$ dan $50 \mathrm{mg} / \mathrm{mL}$ mampu menekan pertumbuhan B. theobromae dengan indeks antifungi $100 \%$.

\section{SARAN}

Perlu dilakukan studi lanjutan untuk mengungkap jenis senyawa antifungi dan efektifitasnya dalam mengendalikan pertumbuhan cendawan patogen $B$. theobromae.

\section{DAFTAR PUSTAKA}

Abdel-Monaim MF, Abo-Elyousr KAM, Morsy KM. 2011. Effectiveness of plant extracts on suppression of damping-off and wilt diseases of lupine (Lupinustermis Forsik). Crop Protection. 30:185-191.doi:10.1016/j.cropro. 2010.09.016.

Achmad, Anggraeni I, Herliyana EN, Ansori A, Rijal S. 2012. Keefektifan penghambatan ekstrak daging biji picung terhadap pertumbuhan Rhizoctonia sp. dan Cylindrocladium sp. secara in vitro. J Hort. 22(3):268-275.

Aderiye BI, Oluwole OA. 2015. Antifungal agents that target fungal cell wall components: a review. Agric and Biol Sci Journal. 1(05): 206-216.
Aisah AR. 2014. Identifikasi dan patogenisitas cendawan penyebab primer penyakit mati pucuk pada bibit jabon [Anthocephalus cadamba (Roxb). Miq] [tesis]. Bogor (ID):Institut Pertanian Bogor.

Aisah AR, Soekarno BPW, Achmad. 2015. Isolasi dan identifikasi cendawan yang berasosiasi dengan penyakit penyakit mati pucuk pada bibit jabon (Anthocephalus cadamba (Roxb.) Miq. J Penelitian Hutan Tanaman. 12(3):153-163.

Chye FY, Sim KY. 2009. Antioxidative and antibacterial activities of Pangium edule seed extracts. Int $J$ Pharmacol. 5(5):285297.doi:10.3923/ijp.2009. 285.297.

Ellis D, Davis S, Alexiou H, Handke R, Bartley R. 2007. Description of Medical Fungi Ed ke-2. Adelaide (AU): School of Molecular and Biomedical Science University of Adelaide.

Falah S, Safithri M, Katayama T, Suzuki T. 2010. Hypoglycemic effect of mahogany (Swietenia macrophylla King) bark extracts in alloxaninduced diabetic rats. Wood Research Journal. 1(2):89-94.

Johnny L, Yusuf UK, Nulit R. 2010. The effect of herbal plant extracts on the growth and sporulation of Colletotrichum gloeosporioides. J Applied Biosci. 34:2218-2224.

Johnny L, Yusuf UK, Nulit R. 2011. Antifungal activity of selected plant leaves crude extracts against a pepper anthracnose fungus, Colletotrichum capsici (Sydow) butler and bisby (Ascomycota: Phyllachorales). African J Biotechnol. 10(20):4157-4165.doi:10.5897/ AJB10.2085.

Lim TK. 2013. Edible Medicinal and Non-Medicinal Plants. Volume 5. Fruits. Dordrecht (NL): Springer Science Business Media. hlm 780781.doi: 10.1007/978-94-007-5653-3_42.

Markson AA, Amadioha AC, Omosun G, Madunagu BE, Udo SE, Umana EJ. 2012. Control of Botryodiplodia theobromae causing tissue rot of white yam (Dioscorea rodunata Poir). Scholarly J Agric Sci. 2(1):1-7.

Mattjik AA, Sumertajaya IM. 2013. Perancangan Percobaan dengan Aplikasi SAS dan Minitab. Jilid I. Bogor (ID): IPB Pr.

Mora E, Emrizal, Mulyantika E. 2014. Isolasi senyawa dari ekstrak etil asetat daun kepayang (Pangium 
edule Reinw.) dan uji aktivitas anti bakteri. Farmasains. 2(3).

Partomihardjo T, Rugayah. 1989. Pangi (Pangium edule Reinw.) dan potensinya yang mulai dilupakan. Media Konservasi. 2(2):45-50.

Pedraza JMT, Aguilera JAM, Diaz CN, Ortiz DT, Monter AV, Mir SGL. 2013. Control of Lasiodiplodia theobromae the causal agent of dieback of sapote mamey [Pouteria sapote (Jacq) HE Moore y Stearn] in Mexico. Rev Fitotec Mex. 36(3):233-238.

Salisbury FB, Ross CW. 1995. Fisiologi Tumbuhan Jilid II. Diah RL, Sumaryono, penerjemah. Bandung (ID): ITB Pr. Terjemahan dari: Plant Physiology. Ed ke-4.

Sari R, Suhartati. 2015. Pangi (Pangium edule Reinw.) sebagai tanaman serbaguna dan sumber pangan. Info Teknis EBONI [Internet]. [diunduh $2016 \mathrm{Feb}$ 25]; 12(1):23-37. Tersedia pada: http://balithutmakassar.org/wpcontent/uploads/2014/11/3_Pangium-edule_InfoTeknis-Eb oni-Vol-12-No-1-2015.pdf.

Scott P. 2008. Physiology and Behaviour of Plant. Chichester (UK): J Wiley.

Sortino M, Derita M, Svetaz L, Raimondi M, Di Liberto M, Petenatti M, Gupta M, Zacchino S. 2012. The role of natural products in discovery of new antiinfective agents with emphasis on antifungal compounds. Di dalam: Valdir Cechinel-Filho V, editor. Plant Bioactives and Drug Discovery Principles, Practice and Perspectives. Brazil (BR): J Wiley. hlm 205-239.

Suhardi. 2009. Isolasi dan karakterisasi ekstrak kasar daun pakem (Pangium edule Reinw.) sebagai penghambat bakteri patogen dan pembusuk daging. J Teknol Pert. 4(2):84-95.

Syahbirin G, Batubara I, Setiawati T, Nulhakim L. 2005. Senyawaaktif daun picung (Pangium edule
Reinw.) sebagai insektisida botani terhadap ulat gerayak (Spodoptera litura F.) (Lepidoptera: Noctuidae). Prosiding Simposium Nasional Kimia Bahan Alam XV [internet]. 2005 Sep13-14; Bogor, Indonesia. Bogor (ID): Departemen FMIPA IPB. Hlm 56-66. [diunduh 2016 Mar 02]. Tersedia pada: http://repository.ipb.ac.id/ bitstream/handle/123456789/51057/gustini\%20sya hbirin_.pdf?sequence $=2 \&$ isAllowed $=y$.

Twumasi P, Ohene-Mensah G, Moses E. 2014. The rot fungus Botryodiplodia theobromae strains cross infect cocoa, mango, banana, and yam with significant tissue damage and economic losses. African $J$ of Agric. 9(6):613619.doi:10.5897/AJAR2013.7528.

Vyas SC. 1984. Systemic Fungicides. New Delhi (IN): Tata McGraw-Hill Publishing Company Limited.

Watanabe T. 2002. Pictorial Atlas of Soil and Seed Fungi Morphologies of Cultured Fungi and Key to Species. Ed ke-2. Boca Raton (US): CCR Pr.

Wiart C. 2006. Medicinal Plants of The Asia-Pacific: Drugs for The Future?. Toh Tuck Link (SN): World Scientific Publishing. hlm 177.

Winara A. 2014. Bioaktivitas ekstrak mahoni dan identifikasi jenis isolat Botryodiplodia sp. penyebab mati pucuk pada bibit jabon [tesis]. Bogor (ID): Institut Pertanian Bogor.

Yang H, Zhang H. 2012. Synergistic interaction of tea saponin with mancozeb against Pestalotiopsis theae. Crop Protection. 40:126-131.doi:10.1016/ j.cropro.2012.04.013.

Yanti LA, Achmad, Khumaida N. 2015. Uji resistensi bibit jabon putih dan merah (Anthocephalus spp.) terhadap Botryodiplodia theobromae (Pat.) penyebab penyakit mati pucuk. J Silvikultur Tropika. 06(2):83-92. 